\title{
Investigating the Role of Service Quality and Satisfaction on Debtor Loyalty Behavior
}

Edy Bambang Wibowo

Sebelas Maret University, Indonesia

E-mail: edy_wibowo@bca.co.id

Phone: +62 812-2615-603

Indonesia

Retno Tanding Suryandari

Sebelas Maret University, Indonesia

E-mail: feb@unit.uns.ac.id

Phone: +62 811-2632-248

Indonesia

\section{ABSTRACT}

The current global economic challenges force each country to survive for the prosperity of its people. The banking sector, as one of the economic regulators, also helps to grow GDP. In this effort, the bank continues to strive to maintain customer satisfaction and build long-term relationships. Although many studies examine satisfaction, there are no studies that reveal the role of punctuality and convenience of service as solid constructs in explaining the process of bank customer loyalty behavior. The purpose of this article is to examine the relationship between timeliness and service convenience to satisfaction-mediated loyalty. This paper is a conceptual study so that there are several prepositions explained. The implications of this article are expected to give alternative insight to marketing literature, especially in the field of banking marketing, as well as a foundation that can later be investigated empirically for future researchers.

\section{Keywords: Service Quality; Banking, Timeliness; Service Convenience; Satisfaction; Loyalty}

\section{INTRODUCTION}

To ensure customer satisfaction and loyalty, as one of the service industries, banks must focus on their service quality. Today, comprehensive banking service-quality models have identified the key antecedents of customer loyalty, including multidimensional models of service quality and other factors that contribute to customer loyalty [1].

The banking industry must face much uncertainty from the trade war between the US and China, not to mention the global recession as a result of the covid-19 pandemic. This industry also deals with the strict competition with non-bank and fintech companies. The recorded value of Fintech loans as of June 2019 is IDR 44.8 trillion (OJK's data). Findings by Pricewaterhouse Coopers $(\mathrm{PwC})$ Indonesia stated that the development of fintech is one of the risks for the national banking industry. This finding is based on the 2018 Indonesia Banking Survey report of 65 respondents from 49 banks in Indonesia. As many as $41 \%$ of respondents from large banks stated that fintech will become a serious threat in the next five years. Thus, banks must retain existing customers and make a high level of loyalty from customers. Understanding these antecedents helps managers to improve the debtor's loyalty.

The largest income from the banking industry comes from loan interest. Each bank not only competes for new debtors but must also pay attention to the quality of its credit. One indicator of credit quality is reflected in the Nonhttps://ijbassnet.com/
Performing Loan (NPL) indicator, while Indonesia's banking NPL trend itself has decreased. Data from the Financial Services Authority of Indonesia shows that the NPL of Indonesian banks in 2019 was $2.53 \%$, increased only a few from 2018 , for $2.37 \%$.

Since the biggest profit for a bank is obtained from providing credit, each bank competes to gain new creditors and still needs to pay attention to the quality of its credit, considering that the National Banking Non-Performing Loan (NPL) in 2019 was at the level of $2.53 \%$. Alas, the year 2020 is a challenging period for the banking industry as the Covid19 pandemic has quite hindered economic performance in general. The Financial Services Authority projects that the NPL in 2020 will only reach $3 \%$. This becomes a concern for the banking industry to be more prudent in the distribution of credit. This study takes the object of BCA bank, which is the largest private bank in Indonesia. Data from BCA bank shows that the NPL in 2018 was at the level of $1.40 \%$ and improved in 2019 at the level of $1.30 \%$. However, the NPL in semester 1 of 2020 showed a decline in performance with an NPL level of $2.08 \%$. This shows that it is important for banks to continue to improve the level of satisfaction and loyalty of debtors.

The concept of consumer loyalty in the service industry is considered to be a significant point in the marketing literature [2]. Previous studies by Haron et al., (2020) found that satisfaction is a key post-consumption to construct loyalty. http://dx.doi.org/10.33642/ijbass.v7n4p2 


\section{CCenter for Promoting Education and Research (CPER) USA}

WWW.cpernet.org

Zeithaml et al., (1996) define customer satisfaction as based on the balance between customers' expectations and customers' experiences with the products and services. Another definition by Kotler \& Keller (2013) established customer satisfaction as a customer's feelings of pleasure or disappointment resulting from comparing the product's perceived performance to customers' expectations.

Consumer service quality evaluations could vary from context to context [5]. Prior studies show the dynamic relationship between service quality and satisfaction [2], [6], [7]. A study by Özkan et al., (2019) in the Turkish banking industry found that service quality positively affects customer satisfaction. Yilmaz et al., (2018) investigated the relationship between service quality dimensions, customer satisfaction, and loyalty in the Turkish banking sector.

Furthermore, this study also examines the relationship between satisfaction and loyalty. While many studies found that customer satisfaction has a positive effect on customer loyalty, the concept of customer loyalty itself has received a lot of attention from academics and practitioners in various industries [1], [2], [10], [11]

In an increasingly competitive market, the ability to build consumer loyalty is seen as a key factor in winning market share and developing a sustainable competitive advantage. Relatively, the role of satisfaction as a mediating factor for customer loyalty has been widely found in previous studies [12]-[15]. Those studies also highlighted that satisfaction tends to have a mediating effect instead of a moderating effect when it comes to customer loyalty.

While the majority of previous research focuses on the consumer behavior of banking customers in general, this research specifically examines the behavior of customers who use loan services or debtors. The academic concern for addressing this specific type of customer is still quite limited [16]. Therefore, focusing on the gap hopefully would bring some new insight to the marketing literature, especially in banking services. Finally, this study also examines the differences in the level of satisfaction and loyalty of two groups of debtors: large debtors who have a total loan amount of more than 15 billion rupiahs and small debtors with loans below 15 billion rupiahs.

\section{LITERATURE REVIEW}

This research is based on the confirmationdisconfirmation construct, which explains the process of customer satisfaction behavior. This paradigm was originally conceptualized in 1980 by Richard L. Oliver and is still extensively accepted and used in research on customer satisfaction. The paradigm is later developed by Barsky (1992) as the theory of disconfirmation of expectations. The expectancy disconfirmation theory was explained by proposing that the level of satisfaction is the result of calculating the expected and perceived performance. Satisfaction or positive disconfirmation occurs when a product or service is better than expected. On the other hand, if the actual performance is worse than expected, it will result in dissatisfaction or negative disconfirmation [17].

\section{Service Quality and Customer Satisfaction}

Service quality is a logical driver of perceived value [18]. Grönroos, (1993) suggests that consumers assess service quality by comparing what they feel with the actual performance provided by the company. The study of Parasuraman et al., (1988), stated that SERVQUAL consists of five dimensions, tangibles, reliability, responsiveness, assurance, and empathy. Instruments on the SERVQUAL dimension use a calculated disconfirmation approach in which the difference or gap between customer expectations and actual performance. The SERVQUAL model integrates several constructs and proposes that the perception of service quality, which in this study consists of five dimensions, is an antecedent to customer satisfaction. This also strengthens the results of previous studies that show that service quality leads to customer satisfaction.

The prior studies focus on banking-service research conceptualized service quality as a hierarchical, multidimensional construct [1], [9]. The study model considers service quality as a hierarchical, multidimensional, second-order construct, formed by its first-order service-quality dimensions measured through several questioner items. Previous studies have also adopted the SERVQUAL framework and have assessed the reliability and validity of these measurements so that SERVQUAL became the most widely applied and tested general scale for service quality [21], [22]. This instrument has been broadly used by both managers and academics to evaluate customer perceptions of service quality for various services [23].

In the modern banking system, maintaining and advancing long-term customer relationships is essential for a competitive business, particularly in boosting customer satisfaction. A previous study by [24] examined the relationship between service quality and customer satisfaction in the banking sector. The result showed that the relationship between the two variables was significant. Awan et al., (2011) analyzed SERVQUAL and customer satisfaction in the Pakistani banking sector. The evidence presented in the study shows that the relationship between customer satisfaction and service quality validates the importance of the service quality aspects of the banking sector in Pakistan. From the literature mentioned above, we propose Hypothesis 1:

H1. Perceptions of service quality (SERVQUAL) positively affect customer satisfaction

\section{Satisfaction and Loyalty}

Customer satisfaction is the customer's overall attitude based on the experience of purchasing a product or using a service. Satisfaction is a feeling resulting from the difference between expectation and experience [1]. Based on the expectation disconfirmation theory by Oliver, (1977), 


\section{(C) Center for Promoting Education and Research (CPER) USA}

WWW.cpernet.org

customer satisfaction results from the process where consumers compare their expectations and perceptions of performance.

Previous research has extensively reviewed the effect of customer satisfaction on loyalty. A study by Jamal \& Anastasiadou, (2007) found a significant relationship between satisfaction and loyalty on two retail banking customers in Greece. It is also confirmed by Boonlertvanich, (2019) that found similar findings regarding the behavior of Thai banking customers. Customer satisfaction is also related to loyalty in Islamic banks [3]. However, for the majority of previous studies that focused on general banking customer consumer behavior, the research that specifically addresses banking debtor behavior is still limited. Thus, it is necessary to address this gap and investigate whether there is an alternative result concerning this specific banking customer.

Correspondingly, there is also a gap study in previous research related to the relationship between satisfaction and loyalty. One of the findings of a study from Pritchard et al., (1998) states that customer satisfaction, which accumulates over time, has a direct effect on customer loyalty to a brand (brand loyalty). On the other hand, Matos et al., (2013) revealed that satisfied customers are not always loyal customers. Customers may maintain their relationship with the company even though they are dissatisfied. Based on these findings, we propose a second hypothesis:

\section{H2. Customer satisfaction positively affect loyalty}

\section{The Mediating Role of Satisfaction}

Prior research found that satisfaction acts as a moderator between service quality and loyalty in three of the four industries studied, while in subsequent studies, it has been found that satisfaction acts more as a mediator than as a moderator. A study by [12] examined the relationship between service quality and the mediating role of customer satisfaction in the banking sector using SEM analysis tools and regression analysis. The results of these studies indicate that customer satisfaction has a mediating role between loyalty and service quality. Similarly, [14] found that customer satisfaction acts as an intermediary variable between the dimensions of service quality, perceived price and fairness, dimensions of service convenience, and customer loyalty. Based on these remarks, we propose a second hypothesis:

H3. Customer satisfaction mediates the relationship between perceived service quality (SERVQUAL) and customer loyalty

\section{Customer Loyalty}

Service loyalty is based on a positive attitude and behavior toward a service provider, preventing customers from switching to another provider [12]. The concept of customer loyalty is recognized as a combination of customers' favorable attitudes and behavior. Then it manifested through the willingness of customers to recommend that product/service to others and repeat purchases. Loyal customers also bring enormous advantages to the company, such as allowing for a continuous profit stream and reduction of marketing/promotion costs [28].

Academics and marketers have long acknowledged the construct of loyalty as valuable tools for developing effective marketing strategies. This concept has been expanded to cover a wide range of products and services, including banking services. Jain et al., (1987) stated that a lack of loyalty could lead to switching intention to other service providers. Moreover, a customer will show loyalty to a product or service from a company when this product/service meets customer needs in the best possible way.

In the banking sector, customer loyalty is directly influenced by satisfaction and service quality [30] conducted a study which verified that satisfaction, service quality, and trust have a significant effect on loyalty, with satisfaction be the most significant determinant. Hence, the bank needs to pay attention to service quality to boost customer loyalty to the company.

Figure 1 presents the research model in this study. This model is conceptualized to dig into the phenomena related to debtor loyalty to banking services in Indonesia. This study focuses on the process of loyalty behavior and its connection with the antecedents, including the dimension of service quality and satisfaction. The model was build based on previous studies with the SERVQUAL instrument based on the verdicts by Parasuraman et al., (1988).

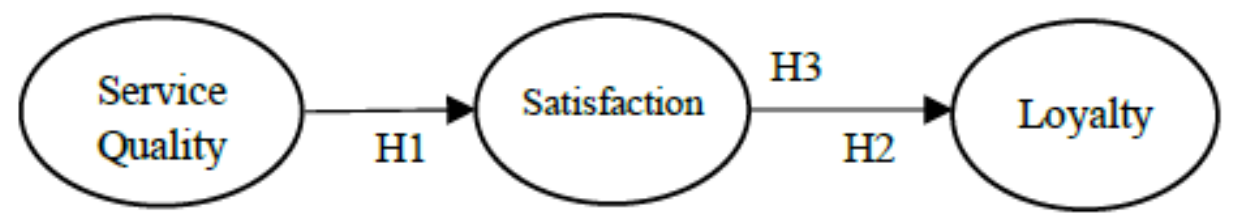

Figure 1. Research Framework

\section{METHODS}

The population in this research is bank customers who use loan or credit services at BCA bank, the largest bank in Indonesia. Furthermore, the criteria for the sample of respondents used in this study are the active non-MSME debtors who use the services with a loan range of 1 - 500 billion rupiah. Sampling was done by convenience sampling method. Researchers provide a set of questionnaires that are distributed online to respondents. This method gave the writer the advantage in terms of time and freedom to choose respondents by utilizing the advancement of digital technology. 
The data collection for this study was carried out in Surakarta, Indonesia. Data gathering focused on banking credit service customers. The survey questionnaire was prepared using Google Form and distributed via email, forums, and personal contacts to respondents. Aside from reaching further respondents and use time efficiently, we carried this method following the current pandemic conditions that require minimizing physical contact between people.

The questionnaire items were adopted from previous research. The original questionnaire is written in English, so we used an Indonesian translation for the respondents to be able to collect the relevant answer from the Indonesian respondents. We also back-translated the questions to keep the meaning and validity of the questionnaire indicators maintained.

\section{RESULT AND DISCUSSION}

Descriptive Statistic
The SERVQUAL variable was measured by adopting 22 items compiled by Parasuraman et al., (1988), consisting of five dimensions: reliability, assurance, tangibility, empathy, and responsiveness. Meanwhile, the satisfaction variable is measured by 5 items proposed by [1]. The loyalty variable is measured by 5 items proposed by [1] and [31]. Furthermore, each item is assessed using a 5-point Likert scale. These numbers represent 1 for strongly disagree, 2 for disagree, 3 for neutral, 4 for agree, and 5 for strongly agree. To determine the quality of the data collection instrument, a pilot study was initially conducted on 30 individuals. Questions that were difficult to understand were removed from the questionnaire, while some of the other questions were modified, as necessary.

Table 1

Sample's Demographic Information

\begin{tabular}{|c|c|c|}
\hline Variable & Frequency & Proportion (\%) \\
\hline \multicolumn{3}{|l|}{ Gender } \\
\hline Male & 110 & 55 \\
\hline Female & 90 & 45 \\
\hline \multicolumn{3}{|l|}{ Age } \\
\hline $21-30$ years old & 20 & 10 \\
\hline $31-40$ years old & 50 & 25 \\
\hline $41-50$ years old & 84 & 42 \\
\hline$\geq 51$ years old & 46 & 23 \\
\hline \multicolumn{3}{|l|}{ Time Length as a Debtor } \\
\hline$<1$ years & 4 & 2 \\
\hline $1-2$ years & 24 & 12 \\
\hline$>2-3$ years & 16 & 8 \\
\hline$>3-4$ years & 28 & 14 \\
\hline$>4$ years & 128 & 64 \\
\hline \multicolumn{3}{|l|}{ Amount of Loans } \\
\hline More than DR 15 B & 27 & 13,5 \\
\hline Less than IDR 15 B & 173 & 86,5 \\
\hline
\end{tabular}

Source: Primary data, processed

Table 1 presents information regarding the demographic characteristic of the debtor who participated in $\mathrm{f}=20$ ). the survey. The results of the descriptive test showed that $55 \%$ of the debtors were male ( $\mathrm{f}=100)$, while $45 \%$ were women $(\mathrm{f}=90)$. This proportion is considered sufficiently balanced to avoid any gender bias that may occur and affect the research results. Further information regarding respondents' age shows that the majority of the sample is in the age range of $41-50$ years $(42 \%, f=84)$, followed by the age range of 31-40years
$(25 \%, f=50), \geq 51$ years $(23 \%, f=46)$, and $21-30$ years $(10 \%$,

Furthermore, the proportion of respondents in terms of the time length as debtors was dominated by debtors with a time length of 4 years $(64 \%, f=128)$. The second-largest proportion was debtor with a time length of $>3-4$ years $(14 \%)$, followed by tenor periods of $1-2$ years $(12 \%),>2-3$ years $(8 \%)$, and $<1$ year $(2 \%)$. Then, from all respondents, $86.5 \%$ were debtors with loans above 15 billion rupiahs, and the remaining $13.5 \%$ were debtors with loans less than 15 billion rupiahs. 


\section{Validity and Reliability Test}

As a start, this study uses an outlier test to avoid the weak accuracy of the research model in explaining the phenomenon under study. The outlier test in this study was carried out by identifying the variables and processing the raw data to find the extreme Mahalanobis score. This process is done several times until the extreme score does not appear again. In total, this study discarded 71 data from 200 respondents and left 129 data worthies of further testing.
Next, this study applied both convergent and discriminant validity tests. The result in Table 2 shows that all outer loading values have met the requirements of minimum cut-off according to F Hair Jr et al., (2014), where all items have been grouped in their quadrants and have loadings values greater than 0.5 . We eliminated 5 items with loadings greater than 0.9 to get better CR and AVE values. After eliminating the indicators whose scores are not good enough, the test results show a better score and can be continued to the next test.

Table 2

Validity and Reliability Test

\begin{tabular}{|c|c|c|c|}
\hline Items & $\begin{array}{c}\text { Outer } \\
\text { Loadings }\end{array}$ & $\begin{array}{l}\text { Composite } \\
\text { Reliability }\end{array}$ & AVE \\
\hline Reliability & & 0.927 & 0,717 \\
\hline REA 1 & 0,840 & & \\
\hline REA2 & 0,816 & & \\
\hline REA3 & 0,872 & & \\
\hline REA4 & 0,854 & & \\
\hline REA.5 & 0,850 & & \\
\hline Assurance & & 0,914 & 0,726 \\
\hline ASR 1 & 0,882 & & \\
\hline ASR2 & 0,862 & & \\
\hline ASR3 & 0,840 & & \\
\hline ASR 4 & 0,822 & & \\
\hline Tangibility & & 0,905 & 0,705 \\
\hline TAN1 & 0,865 & & \\
\hline TAN2 & 0,845 & & \\
\hline TAN3 & 0,799 & & \\
\hline TAN4 & 0,849 & & \\
\hline Enpathy & & 0,925 & 0,755 \\
\hline EMP1 & 0,867 & & \\
\hline EMP3 & 0,862 & & \\
\hline EMP4 & 0,846 & & \\
\hline EMPS & 0,899 & & \\
\hline Responsiveness & & 0,929 & 0,813 \\
\hline RES1 & 0,901 & & \\
\hline RES2 & 0,908 & & \\
\hline RES3 & 0,896 & & \\
\hline Satisfaction & & 0,929 & 0,767 \\
\hline SAT1 & 0,874 & & \\
\hline SAT2 & 0,890 & & \\
\hline$S A T 4$ & 0,893 & & \\
\hline SATS & 0,844 & & \\
\hline Loyalty & & 0,922 & 0,798 \\
\hline LOY2 & 0,892 & & \\
\hline LOY3 & 0,922 & & \\
\hline LOYS & 0,865 & & \\
\hline
\end{tabular}

Table 2 also shows that all variables and dimensions the criteria with a value greater than 0.7. Hence, the results meet the acceptable cut-off value, which means that the shown in Table 2 show that the instrument is reliable and has instrument is convergently accepted. The indicator of the shown the consistency of all indicators in measuring its composite reliability value from Table 2 appears to have met construct so that it can be used for further testing.

Table 3

Fornell-Lecker Criterion

\begin{tabular}{llllllll}
\hline Variable & ASR & EMP & LOY & REA & RES & SAT & TAN \\
\hline ASR & $\mathbf{0 , 8 5 2}$ & & & & & & \\
EMP & 0,827 & $\mathbf{0 , 8 6 9}$ & & & & & \\
LOY & 0,652 & 0,658 & $\mathbf{0 , 8 9 3}$ & & & & \\
REA & 0,836 & 0,838 & 0,745 & $\mathbf{0 , 8 4 7}$ & & & \\
RES & 0,795 & 0,828 & 0,695 & 0,812 & $\mathbf{0 , 9 0 2}$ & & \\
SAT & 0,746 & 0,756 & 0,815 & 0,807 & 0,772 & $\mathbf{0 , 8 7 6}$ & \\
TAN & 0,719 & 0,757 & 0,625 & 0,782 & 0,727 & 0,743 & $\mathbf{0 , 8 4 0}$ \\
\hline
\end{tabular}

Source: Primary data, processed 


\section{(C) Center for Promoting Education and Research (CPER) USA}

WWW.cpernet.org

Table 3 shows the discriminant validity test result variance shared with its indicator group is greater than the using the Fornell-Larcker criteria indicators. It can be seen that variance that is shared with the other latent variable. Thus, the all values on the diagonal which are the roots of AVE each instrument has fulfilled the discriminant validity aspects variable have a greater loading than the loading on other according to Fornell and Larcker's criterion. indicators below. This means that for each latent variable, the

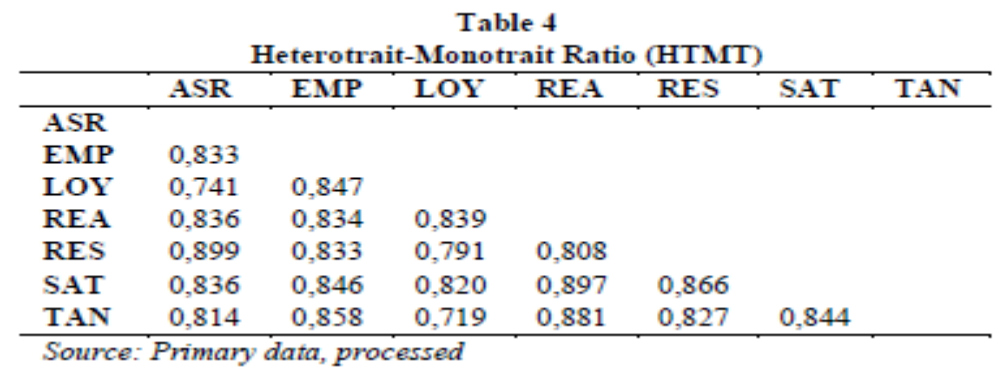

Furthermore, since there has been some criticism validity is lower than 0.90 , and as shown in Table 4 , all the regarding the Fornell-Larcker criterion to assess validity, [33] HTMT values are below 0.90, indicating that discriminant suggested an alternative approach based on the multitrait- validity has been assured. multimethod matrix. The acceptable level of discriminant

\section{HYPOTHESES ANALYSIS AND DISCUSSION}

The next step was to examine if the proposed model is consistent as a construct that could provide valuable insights. The model was tested using the path coefficient on SmartPLS 3 . The result in Table 5 indicates that service quality has a significant effect on debtor satisfaction (O: 0.838, SD: 0.029, t for value: $29.246, \mathrm{p}<0.01$ ), so hypothesis 1 is supported. This result confirms previous studies [24], [34] that examined customer perceptions of service quality on satisfaction in the banking sector. This again proves the importance of aspects of service quality in building customer satisfaction, particularly Table 5

\begin{tabular}{|c|c|c|c|c|}
\hline & $\begin{array}{c}\text { Original } \\
\text { Sample } \\
(\mathrm{O})\end{array}$ & $\begin{array}{l}\text { Standard } \\
\text { Deviation } \\
\text { (STDEV) }\end{array}$ & $\begin{array}{l}\text { T Statistics } \\
(|\mathrm{O} / \mathrm{STDEV}|)\end{array}$ & $\begin{array}{c}P \\
\text { Values }\end{array}$ \\
\hline $\begin{array}{l}\text { H1. Servqual } \\
\text { Perception-> } \\
\text { Satisfaction } \\
\text { H2. }\end{array}$ & 0,838 & 0,029 & 29,246 & 0,000 \\
\hline $\begin{array}{l}\text { Satisfaction-> } \\
\text { Loyalty } \\
\text { H3. Servqual } \\
\text { Perception >> } \\
\text { Satisfaction-> } \\
\text { Loyalty }\end{array}$ & 0,815 & 0,033 & 24,812 & 0,000 \\
\hline
\end{tabular}

The second hypothesis explains the relationship relationship between service quality and loyalty (O: 0.683 , SD: between satisfaction and loyalty. The result shows a significant 0.041 , t value: $16.802, \mathrm{p}<0.01)$. So it can be concluded that $\mathrm{H} 3$ effect (O: 0.815 , SD: $0.033, \mathrm{t}$ value: $24.812, \mathrm{p}<0.01$ ), is accepted. These results are in line with the previous study supporting the hypothesis. It also confirms previous findings that examines the mediating role of satisfaction in the banking by Jamal \& Anastasiadou, (2007) on their study in retail sector [3], [12], [14] Companies that have done their banking customers in Greece and in a study conducted by [1], responsibilities, which automatically encourages debtors to confirming similar findings on banking customer behavior in Thailand. Moreover, even though several other studies in the banking sector show that satisfaction does not lead to loyalty [27], this study highlights that satisfied customers tend to be loyal, especially when the relationship between customers and banking companies has been established for a long time. The findings also emphasize that customer satisfaction, which accumulates over time, has a direct effect on brand loyalty [26]. The results also show that satisfaction mediates the have good relationships with the bank. Furthermore, service quality indirectly affects customer loyalty. Customers who perceive positively towards the service will believe that the bank is behaving professionally in fulfilling customers' needs. Our study separates the data into two groups between debtor that has < IDR 15 billion and debtor that has> IDR 15 billion lendings. The multi-group analysis also found that there is no difference between the two groups. 
Table 6

PLS-MGA Analysis on Debtor $<15 \mathrm{~B}$ vs $>15 \mathrm{~B}$

\begin{tabular}{|c|c|c|c|c|}
\hline \multirow{2}{*}{$\begin{array}{l}\text { Hypothesized } \\
\text { relationship }\end{array}$} & \multicolumn{2}{|c|}{$\begin{array}{l}\text { Standardized path coefficient } \\
\text { (t-value) }\end{array}$} & \multirow{2}{*}{$\begin{array}{c}\text { path } \\
\text { coefficient } \\
\text { differences } \\
(<5 \text { B vs }> \\
15 \text { B) }\end{array}$} & \multirow{2}{*}{$\begin{array}{c}\text { p- } \\
\text { Value } \\
(<5 \mathrm{~B} \\
\text { vs > } \\
15 \mathrm{~B})\end{array}$} \\
\hline & $<5 \mathrm{~B}$ & $>15 \mathrm{~B}$ & & \\
\hline ServQual $\rightarrow$ & $0,834^{* * *}$ & $0,860 * * *$ & & \\
\hline Satisfaction & $(25,927)$ & $(19,372)$ & 0,020 & 0,055 \\
\hline Satisfaction & $0,822^{* * *}$ & $0,768 * * *$ & 0055 & 0326 \\
\hline$\rightarrow$ Loyalty & $(25,067)$ & $(7,733)$ & & \\
\hline $\begin{array}{l}\text { ServQual } \\
\rightarrow \text { Satisfction } \\
\rightarrow \text { Loyalty }\end{array}$ & $\begin{array}{c}0,691^{* * *} \\
(16,073)\end{array}$ & $\begin{array}{c}0,660 * * * \\
(6,519)\end{array}$ & 0,031 & 0,423 \\
\hline
\end{tabular}

Furthermore, the test was carried out on 2 categories of respondents consisting of debtors with a loan value of $<15$ billion and a loan value of $>15$ billion. The test results using Multi-Group Analysis contained in Table 6 show the p-value on the relationship between service quality and satisfaction of 0.655 and the $p$-value on the relationship between satisfaction and loyalty of 0.326 . Both results show a $p$ value $>0.1$, so it can be concluded that there is no significant difference in response between debtors with a loan value of $<15$ billion and borrowers with a loan value of $>15$ billion.

\section{CONCLUSION AND IMPLICATION}

This study shows the importance of maintaining service quality and establishing satisfaction in the banking sector. When debtors are satisfied, they act favorably towards the banking. This research also validates previous research regarding the relationship between the dimensions of SERVQUAL, satisfaction, and loyalty. In this research, it is clear banking companies could initiate loyalty through the role of service quality and customer satisfaction. The SERVQUAL dimension consisting of reliability, assurance, tangibility, empathy, and responsiveness contributes to nurturing longterm relationships with customers, especially debtors, through the impact of satisfaction that coming from the quality of services provided. Relatively, this study strengthens the confirmation-disconfirmation theory concerning the process of consumer loyalty behavior. The theory provides a solid foundation for the research model and helps to explain the issues addressed within the scope of this study.

Further, this study provides recommendations for service providers, especially banking companies, to actively improve the quality of their services and integrate them into the company's marketing strategy. In addition to improving service quality to boost satisfaction, banking companies can also maintain debtor trust and loyalty through the factors that support positive behavior. Increasing debtor satisfaction can be achieved by expanding the benefits through the product or service offered. In addition to improving the products or services offered, banks need to provide services and product innovations with better value. Finally, building good long-term relationships can also be done through physical banking features along with the service attributes provided by employees.

\section{LIMITATION AND FUTURE RESEARCH}

The sample size in this study is not large, but it is sufficiently representative and appropriate for data analysis in the study. Of the number of samples that can be collected, some of them cannot be used for further statistical testing. This limitation is alleged because debtors who are the object of study in Indonesia tend to give perfect scores on questionnaires related to the satisfaction that is usually carried out by banks. Also, the occurrence of social distancing as a result of the pandemic has resulted in data collection being mostly done online. This method causes a lack of supervision and assistance for respondents in filling in the data needed in the study.

Also, the object of this research is focused on customers who use loan services, which impacts the generalization of the research model. This condition provides opportunities for further research, especially in developing models in a broader context. Future studies may focus on identifying specific factors or developing alternative measures that help build loyalty in the banking sector. Future research can also develop a richer model and combine other constructs outside the ones in this study and observe their effect on debtor behavior. The role of service quality and satisfaction in fostering loyalty has proven to be an interesting field of study, making it possible for other researchers in the future to dig deeper into these issues and phenomena. Moreover, further research must be careful in seeing the characteristics of the research object. This is important because this study has limited applications. Therefore, there needs to be an ongoing explanation, especially regarding the development of measurements in other settings. 


\section{(C) Center for Promoting Education and Research (CPER) USA}

WWW.cpernet.org

\section{REFERENCES}

K. Boonlertvanich, "Service quality, satisfaction, trust, and loyalty: the moderating role of main-bank and wealth status," Int. $J$. Bank Mark., vol. 37, no. No 1, pp. 278-302, 2019, doi: 10.1108/IJBM- 02-2018-0021.

R. C. Caceres and N. G. Paparoidamis, "Service quality, relationship satisfaction, trust, commitment and business-to-business loyalty," Eur. J. Mark., vol. 41, no. 7/8, pp. 836-867, 2007, doi: 10.1108/03090560710752429.

R. Haron, N. Abdul Subar, and K. Ibrahim, "Service quality of Islamic banks: satisfaction, loyalty and the mediating role of trust," Islam. Econ. Stud., vol. 28, no. 1, pp. 3-23, 2020, doi: 10.1108/IES-12-2019- 0041.

V. Zeithaml, L. Berry, and A. Parasuraman, “The Behavioral Consequences of Service Quality,” J. Mark., vol. 60, pp. 31-46, Apr. 1996, doi: 10.2307/1251929.

A. Parasuraman, V. A. Zeithaml, and A. Malhotra, "E-S-Qual: A Multiple-Item Scale for Assessing Electronic Service Quality," J. Serv. Res., vol. 7, pp. 1-21, 2005, doi: 10.1177/1094670504271156.

N. Asnawi and M. A. Fanani, "The role of service quality within Indonesian customers satisfaction and loyalty and its impact on Islamic banks," J. Islam. Mark., vol. 11, no. 1, pp. 192-212, 2019, doi: 10.1108/JIMA- 03-2017-0033.

S. Famiyeh, D. Asante-Darko, and A. Kwarteng, "Service quality, customer satisfaction, and loyalty in the banking sector: The moderating role of organizational culture," Int. J. Qual. Reliab. Manag., vol. 35, no. 8, pp. 1546-1567, Jan. 2018, doi: 10.1108/IJQRM-01-2017-0008.

P. Özkan, S. Süer, İ. K. Keser, and İ. D. Kocako, "The effect of service quality and customer satisfaction on customer loyalty The mediation of perceived value of services," Int. J. Bank Mark., vol. 38, pp. 384-405, 2019, doi: 10.1108/IJBM-032019-0096.

V. Yilmaz, E. Ari, and H. Gürbüz, "Investigating the relationship between service quality dimensions, customer satisfaction and loyalty in Turkish banking sector An application of structural equation model," Int. J. Bank Mark., vol. 36, no. 3, pp. 423-440, 2018, doi: 10.1108/IJBM-02- 2017-0037.

A. Jamal and K. Anastasiadou, "Investigating the effects of service quality dimensions and expertise on loyalty," Eur. J. Mark., vol. 43, pp. 398-420, 2007, doi: 10.1108/03090560910935497.

V. Kaura, "Service Convenience, Customer Satisfaction, and Customer Loyalty: Study of Indian Commercial Banks," J. Glob. Mark., vol. 26:1, pp. 18-27, 2013, doi: 10.1080/08911762.2013.779405.

A. Caruana, A. H. Money, and P. R. Berthon, "Service quality and satisfaction - the moderating role of value," Eur. J. Mark., vol. 34, pp. 1338-1352, 2000.

G. Fullerton and S. Taylor, "Mediating, Interactive, and Non-linear Effects in Service Quality and Satisfaction with Services Research," Can. J. Adm. Sci. Rev. Can. des Sci. I'administration, vol. 19(2), pp. 124-136, 2002.

V. Kaura Ch, D. Prasad, and S. Sharma, "International Journal of Bank Marketing," Int. J. Bank Mark., vol. 33, no. 4, 2015.

C. Makanyeza and C. Lovemore, "Mediators of the relationship between service quality and customer loyalty: evidence from the banking sector in Zimbabwe," Int. J. Bank Mark., vol. 35, no. 3, 2017, doi: 10.1108/IJBM-11-2016-0164.

N. Limakrisna, D. K. Priatna, and W. Roswina, "Building Customer Loyalty,” Int. J. Eng. Technol., vol. 7, p. 412, 2018.

A. Yüksel and F. Yüksel, “THE EXPECTANCY-DISCONFIRMATION PARADIGM: A CRITIQUE,” J. Hosp. Tour. Res., vol. 25 (2), pp. 107-131, 2001, doi: 10.1177/109634800102500201.

A. Parasuraman and D. Grewal, "Serving Customers and Consumers Effectively in the Twenty-First Century: A Conceptual Framework and Overview," J. Acad. Mark. Sci., vol. 28, pp. 9-16, 2000.

C. Grönroos, “A Service Quality Model and Its Marketing Implications,” Eur. J. Mark., vol. 18, pp. 36-44, 1993, doi: 10.1108/EUM0000000004784.

A. Parasuraman, V. A. Zeithaml, and L. L. Berry, "SERVQUAL: A multiple-item scale for measuring consumer perceptions of service quality.," J. Retail., vol. 64, pp. 12-40, 1988.

L. Bennington and J. Cummane, "M easuring service quality: A hybrid m ethodology," Total Qual. Manag., vol. 9, pp. 395-405, 1998.

S. Sharma, "Using SERVQUAL to Assess the Customer Satisfaction Level: A Study of an Urban Cooperative Bank," J. Econ. Public Financ., vol. 2, no. 1, pp. 57-85, 2016. 
H. M. Awan, K. S. Bukhari, and A. Iqbal, "Service quality and customer satisfaction in the banking sector and Islamic banks in Pakistan,” J. Islam. Mark., vol. 2, no. 3, pp. 203-224, 2011, doi: 10.1108/17590831111164750.

J. J. Cronin and S. A. Taylor, "Measuring Service Quality: A Reexamination and Extension,” J. Mark., vol. 56, pp. 55-68, 1992.

R. L. Oliver, "Effect of Expectation and Disconfirmation on Postexposure Product Evaluations: An Alternative Interpretation," J. Appl. Psychol., vol. 62, no. 4, pp. 480-486, 1977.

M. Pritchard, M. E. Havitz, and D. R. Howard, “Analyzing the Commitment- Loyalty Link in Service Contexts,” J. Acad. Mark . Sci., vol. 27, pp. 333-348, 1998.

C. Augusto De Matos, J. Luiz Henrique, and F. De Rosa, "Customer reactions to service failure and recovery in the banking industry: the influence of switching costs," J. Serv. Mark., vol. 27/7, pp. 526-538, 2013, doi: 10.1108/JSM-01-2012-0019.

H. Han and S. Sean, "International Journal of Hospitality Management Role of motivations for luxury cruise traveling, satisfaction, and involvement in building traveler loyalty," Int. J. Hosp. Manag., vol. 70, pp. 75-84, 2018, doi: 0.1016/j.ijhm.2017.10.024.

A. K. Jain, C. Pinson, and N. Malhotra, "Customer Loyalty as a Construct in the Marketing of Banking Services," Int. J. Bank Mark., vol. 5, no. 3, pp. 49-72, Jan. 1987, doi: 10.1108/eb010811.

O. K. Omoregie, J. A. Addae, S. Coffie, G.O. A. Ampong, and K. S. Ofori, "Factors influencing consumer loyalty: evidence from the Ghanaian retail banking industry," Int. J. Bank Mark., vol. 37, pp. 798-820, 2018, doi: 10.1108/IJBM-042018-0099.

A. Abror, D. Patrisia, Y. Engriani, S. Evanita, Y. Yasri, and S. Dastgir, "customer satisfaction, customer engagement and Islamic bank' s customer loyalty loyalty," J. Islam. Mark., vol. 11, pp. 1691-1705, 2019, doi: 10.1108/JIMA- 03-20190044.

J. F Hair Jr, M. Sarstedt, L. Hopkins, and V. G Kuppelwieser, "Partial least squares structural equation modeling (PLS-SEM): An emerging tool in business research," Eur. Bus. Rev., vol. 26, no. 2, pp. 106-121, Jan. 2014, doi: 10.1108/EBR-102013- 0128 .

J. Henseler and M. Sarstedt, "Goodness-of-fit indices for partial least squares path modeling," Comput. Stat., vol. 28, no. 2, pp. 565-580, 2013, doi: 10.1007/s00180-012-0317-1.

M. A. Abdullah, N. H. A. Manaf, M. Owolabi, K. Ahsan, and S. M. F. Azam, "Determinants of Customer Satisfaction on Retail Banks in New Zealand: An Empirical Analysis Using Structural Equation Modeling," Glob. Econ. Financ. J., vol. 7, pp. 63-82, 2014, doi: 10.21102/gefj.2014.03.71.04. 